\title{
DIKSI PADA KARANGAN NARASI SISWA KELAS VIII C MTs. ALKHAIRAAT KALUKUBULA
}

\author{
Hartati $^{1}$, Idrus $^{2}$ \\ ${ }^{1}$ Program Studi Pendidikan Bahasa dan Sastra Indonesia, FKIP, Universitas Alkhairaat \\ Tati_hartati86@yahoo.com \\ ${ }^{2}$ Program Studi Pendidikan Bahasa dan Sastra Indonesia, FKIP, Universitas Alkhairaat \\ idrusaldjufri@gmail.com
}

\begin{abstract}
ABSTRAK
Penelitian ini bertujuan untuk mendeskripsikan hasil temuan terkait dengan penggunaan diksi pada karangan narasi dan selanjutnya akan dijadikan sebagai sumber belajar siswa. Metode penelitian yang digunakan ialah metode kualitatif. Metode yang digunakan adalah pengumpulan data dengan teknik dokumen. Penelitian ini dilakukan dengan cara mendeskripsikan penggunaan diksi khususnya ketepatan penggunaan diksi dengan tujuh persyaratan ketepatan diksi. Dari hasil analisis yang dilakukan peneliti, maka diperoleh 26 dari 13 karangan narasi siswa. Dari tujuh jenis persyaratan ketepatan diksi yang dianalisis ditemukan lima ketidaktepatan penggunaan diksi yaitu 1) Kata-kata yang bersinonim, 2) Penggunaan kata umum dan kata khusus, 3) Penggunaan kata konotatif dan denotatif, 4) Penggunaan kata indria, 5) Kelangsungan pilihan kata, dan dari data yang diperoleh, ada juga yang tidak ditemukan sesuai syarat ketepatan diksi yaitu 1) Kata Abstrak dan Konkret 2) Pemakaian kata dan istilah asing.
\end{abstract}

Kata Kunci : Diksi, Karangan Narasi.

\begin{abstract}
This research aims to describe the findings about to the use of diction in the narrative essay and then will be used as a source of student learning. The research used qualitative method. The method of data collection is document techniques. This research was conducted by describing the use of diction, especially the accuracy of the use of diction with seven requirements for the accuracy of diction. From the results of the analysis conducted by researchers, 26 of the 13 narrative essays of students were obtained. Of the seven types of diction requirements that were analyzed found five inaccuracies in the use of diction namely 1) Synonyms words, 2) Use of general words and special words, 3) Use of connotative and denotative words, 4) Use of sense words, 5) Continuity of word choices, and from the data obtained, there are also those that are not found according to the requirements for accuracy of diction, namely 1) Abstract and Concrete Words 2) Use of foreign words and terms.
\end{abstract}

Keywords: Diction, Narrative Essay.

\section{PENDAHULUAN}

Bahasa merupakan alat komunikasi yang digunakan seseorang untuk saling berinteraksi. Komunikasi menggunakan bahasa merupakan alat yang sangat penting bagi manusia. Komunikasi tidak dilakukan saat bertatap muka saja, tetapi bisa lewat tulisan. Mereka yang terlibat dalam komunikasi perlu menguasai kosa kata (perbendaharaan kata).

Menurut Tarigan (2008) menulis merupakan salah satu keterampilan berbahasa yang dipergunakan untuk berkomunikasi secara tidak langsung, tidak secara tatap muka dengan orang lain. Dengan menulis kita dapat menuangkan ide atau gagasan yang ada di dalam pikiran, dengan 
menulis pula kita bisa mengutarakan isi hati dan perasaan yang sedang dirasakan melalui media tulis di atas kertas. Namun dalam menulis harus diperhatikan pula penggunaan diksi atau pilihan kata agar pembaca mengerti apa yang disampaikan penulis dalam tulisannya.

Mengarang merupakan pengaplikasian dari menulis dan salah satu materi yang dipelajari di bangku sekolah. Di dalam praktiknya, dalam karangan siswa masih ditemukan kelemahan-kelemahan, terutama ketika menuangkan ide atau gagasan masih banyak siswa yang belum mampu memilih kata (diksi) yang tepat.

Berdasarkan paparan di atas, peneliti tertarik untuk mengetahui dan mempelajari lebih dalam tentang diksi pada karangan narasi siswa. Adapun yang menjadi subjek penelitian ini adalah diksi pada karangan narasi siswa kelas VIIIC MTs. Alkhairaat Kalukubula karena berdasarkan hasil wawancara kepada guru mata pelajaran Bahasa Indonesia dan hasil observasi, peneliti menemukan masih kurangnya pemahaman siswa terutama siswa kelas VIIIC MTs. Alkhairaat Kalukubula tentang penggunaan diksi pada karangan narasi. Oleh karna itu, peneliti berupaya untuk mendeskripsikan kemampuan penggunaan diksi pada karangan narasi siswa di kelas tersebut. Selain itu belum adanya penelitian tentang diksi pada karangan narasi siswa di lingkungan MTs. Alkhairaat Kalubula.

\section{METODE PENELITIAN}

Penulis menggunakan metode penelitian deskriptif kualitatif karena dalam penelitian ini penulis menganalisis diksi dalam karangan siswa kelas VIIIC MTs. Alkhairaat Kalukubula. Bentuk penelitian ini menganilisis dan mendekripsikan penggunaan diksi khususnya ketepatan diksi dalam karangan narasi siswa sebagai sumber belajar bahasa Indonesia. Oleh karena itu, penggunaan metode deskriptif kualitatif ini sesuai untuk mengkaji dan menganilisis data secara obyektif berdasarkan fakta nyata yang ditemukan kemudian memaparkan secara deskriptif, dengan cara menganalisis diksi dalam karangan narasi siswa kelas VIIIC MTs. Alkhairaat Kalukubula.
Peneliti menggunakan metode pengumpulan data dengan teknik studi dokumen, karena data yang digunakan dalam penelitian ini berupa pengumpulan data yang tidak langsung ditujukan kepada subjek peneliti. Dengan menggunkan studi dokumen peneliti melakukan pengumpulan data dengan cara mengumpulkan data, dan menganalisis data yang telah dikumpulkan dengan cara mencatat hasil analisis kemudian akan dideskripsikan sesuai dengan hasil analisis.

Lokasi penelitian adalah MTs. Alkhairaat Kalukubula. Adapun yang menjadi subjek penelitian ini adalah siswa kelas VIII C MTs. Alkhairaat Kalukubula yang berjumlah 20 orang, yang terdiri dari 10 siswa laki-laki dan 10 siswa perempuan.

Peneliti menggunakan metode pengumpulan data dengan teknik studi dokumen, karena data yang digunakan dalam penelitian ini berupa pengumpulan data yang tidak langsung ditujukan kepada subjek peneliti. Dengan menggunkan studi dokumen peneliti melakukan pengumpulan data dengan cara mengumpulkan data, dan menganalisis data yang telah dikumpulkan dengan cara mencatat hasil analisis kemudian akan dideskripsikan sesuai dengan hasil analisis.

Data pada penelitian ini akan dianalisis secara deskriptif kualitatif. Analisis data merupakan proses mencari dan menyususn secara sistematis, data yang diperoleh bisa dari hasil menulis siswa dalam bentuk karangan narasi. Sehinga data dapat mudah dipahami dan hasil dari temuannya dapat diinformasikan kepada orang lain.

Sugiyono (2017) mengemukakan bahwa analisis data kualitatif bersifat induktif, yaitu suatu analisis berdasarkan data yang diperoleh, selanjutnya dikembangkan menjadi hipotesis. Kemudian dicarikan data lagi secara berulang-ulang sehingga dapat disimpulkan apakah hipotesis tersebut diterima atau ditolak berdasarkan data yang terkumpul. Bila berdasarkan data yang dapat dikumpulkan secara berulang-ulang dengan teknik triangulasi, ternyata hipotesis diterima, maka hipotesis tersebut berkembang menjadi teori.

Dalam analisis data ini, peneliti menggunakan teknik studi dokumen. Teknik 
ini adalah dalam penelitian ini peneliti hanya berperan sebagai pengamat penggunaan bahasa oleh informannya, sedangkan peneliti tidak terlibat dalam peristiwa pertuturan yang bahasanya sedang diteliti.

Proses analisis yang digunakan dalam penelitian ini berupa analisis diksi. Dikatakan analisis diksi karena dalam penelitian ini peneliti menganilisis pemilihan kata yang tepat atau diksi dalam karangan narasi siswa kelas VIII MTs. Alkhairaat Kalukubula

Oleh karena itu, penulis menggunakan teknik ini untuk meneliti penggunaan bahasa secara tertulis yakni analisis diksi dalam karangan narasi siswa. Penulis hanya berperan sebagai pengamat penggunaan bahasa terhadap seseorang yang menulis teks karangan narasi dengan mencatat penggunaan diksi dalam karangan narasi siswa kelas VIII C MTs. Alkhairaat Kalukubula.

\section{HASIL DAN PEMBAHASAN}

Hasil penelitian yang diperoleh dari analisis diksi pada karangan narasi siswa kelas VIII C MTs. Alkhairaat Kalukubula. Adapun diksi yang ditemukan sesuai syarat ketepatan diksi yaitu 1) kata-kata yang bersinonim, 2) penggunaan kata umum dan kata khusus, 3) penggunaan kata konotatif dan denotatif, 4) penggunaan kata indria, 5) kelangsungan pilihan kata. Uraiannya dapat dilihat sebagai berikut :

\section{1) Kata-Kata yang Bersinonim.}

Pada saat itu mama irna mengasih kami kue dan minuman, kamipun makan bersama sambil bercerita, bercengkramah dan berfoto-foto.

Kata mengasih pada data (1) mempunyai sinonim memberikan, kata mengasih tidak tepat digunakan karena kata tersebut merupakan dialek sehari-hari.

Keesokkan harinya aku pergi jalanjalan ke kota Toli-toli, sampai di sana aku singgah di pinggir jalan tepat di depan warung bakso, dan akupun diajak oleh pamanku untuk makan bakso.

Kata singgah pada data (2) bersinonim dengan kata mampir dan kata pinggir jalan bersinonim dengan tepi, keduanya memiliki kesamaan makna namun lebih tepat menggunakan kata mampir dan tepi.

\section{2) Penggunaan Kata Umum dan Kata Khusus}

Pada hari minggu tanggal 13/03/2017, tepat pada pukul 08.00 aku dan keluargaku pergi berlibur ke Permandian air panas Bora.

Kata Permandian air panas Bora merupakan kata khusus yang tidak akan menimbulkan salah interpretasi pada pembaca. penulis telah memberikan gambaran secara khusus kepada pembaca agar mengetahui tempat yang dituju.

Pada suatu hari saya dan keluarga berlibur ke rumah nenek di Kampung.

Kata kampung pada kalimat di atas merupakan kata umum. Sebagai kata umum, kampung dapat mencakup pada kata khusus lainnya seperti yang telah dijabarkan pada kalimat tersebut yakni dapat berupa nama kampung atau desa tersebut, misalnya di Ampana, Sigi, Kalukubula dan sebagainya. Penggunaan kata kampung sudah tepat karena penulis sebelumnya telah menjelaskan bahwa dia akan pergi ke kampung neneknya, sehingga tidak menimbulkan salah paham oleh pembaca.

\section{3) Penggunaan Kata Konotatif dan Denotatif}

Pada tanggal 21/06/2018 pukul 05.30, saya bersama keluarga berangkat ke Bandara Mutiara Sis Al-Jufri.

Pada kata 21/06/2018 pukul 05.30 merupakan golongan kata denotatif karena maknanya sudah jelas diketahui, yaitu 21/06/2018 pukul 05.30. Dengan demikian pembaca tidak menginterpretasikan mereka pergi liburan. Jadi penulis sudah tepat dalam menggunakan kata tersebut.

Pada suatu hari aku pergi ke sekolah pada pukul 06.35 WITA.

Frasa pada suatu hari pada kalimat di atas digolongkan dalam kata yang bermakna konotatif, karena Frasa pada suatu hari pada kalimat di atas memiliki makna abstrak. Frasa tersebut tidak menjelaskan secara jelas pada hari apa tepatnya iya pergi kesekolah dan pada hari apa tepatnya kejadian itu terjadi, sehingga pembaca dengan bebas menafsirkan makna dari kata tersebut.

\section{4) Penggunaan Kata Indria}

Disaat aku makan, aku menikmati pemandangan yang indah di tepi laut serta angin sepoi-sepoi yang mengenai tubuhku. 
Kata menikmati pemandangan yang indah pada kalimat di atas merupakan kata yang termasuk diksi indria penglihatan karena diterima oleh mata yang dapat melihat suatu objek, tetapi dalam penggunaan diksi sering kali terjadi kata yang hanya dikenakan pada satu indria bisa digunakan oleh indria yang lain, seperti halnya kalimat di atas penulis menggunakan kata menikmati, kata tersebut termaksud dalam indria perasa. Lebih tepatnya kata menikmati diganti dengan kata melihat, serta kata angin sepoisepoi yang menegnai tubuhku menggunakan indria peraba karena dapat merasakan hembusan angin yang mengenai tubuhnya.

Sesampainya kami di sana, terlebih dahulu kami mampir di tempat permandian Malotong, air ditempat permandian tersebut sangat dingin.

Kata sangat dingin pada kalimat di atas merupakan kata yang termasuk indria peraba karena dapat diterima oleh kulit/tubuh yang dapat merasakan dinginnya air di permandian Malotong tersebut.

\section{5) Kelangsungan Pilihan Kata}

Pada esok harinya aku diajak oleh paman dan bibiku pergi ke pantai dan mandi bersama, akupun sangat senang sekali.

Kata sangat dan kata sekali pada kalimat di atas kurang tepat karena menggunakan kata sangat dan sekali, seharusnya jika sudah mengunakan kata sangat tidak perlu lagi menggunakan kata sekali karena merupakan pemborosan kata. Kalimat yang benar seharusnya " akupun sangat senang".

Di sana aku dan keluargaku sangat senang berkunjung ke Permandian air panas Bora.

Kata Di sana pada kalimat di atas kurang tepat digunakan sebagai kata penghubung diawal paragraf dan diawal kalimat. Seharusnya kata tersebut tidak perlu digunakan, kalimat yang benar " Aku dan keluargaku sangat senang berkunjung ke permandian air panas Bora".

\section{KESIMPULAN DAN SARAN}

Berdasarkan hasil penelitian mengenai penggunaan diksi pada karangan narasi siswa kelas VIII C MTs. Alkhiraat Kalukubula, diperoleh data berupa penggunaan diksi sesuai syarat ketepatan diksi, meliputi 1) kata-kata yang bersinonim, 2) penggunaan kata umum dan kata khusus, 3) penggunaan kata konotatif dan denotatif, 4) penggunaan kata indria, 5) kelangsungan pilihan kata Dari data yang diperoleh, ada juga data yang tidak ditemukan sesuai syarat ketepatan diksi meliputi 1) Kata Abstrak dan Konkret, 2) Pemakaian Kata dan Istilah Asing. Pada karangan narasi tersebut juga ditemukan masih banyak menggunakan dialek seharihari, kata dan kalimat yang tidak baku serta ejaan dan tanda baca yang digunakan masih banyak yang keliru.

Bagi guru mata pelajaran Bahasa Indonesia, hendaknya lebih teliti dalam melihat kesalahan yang dilakukan oleh siswa, seperti kesalahan penggunaan diksi serta kesalahan ejaan dan tanda baca, sehingga dapat menjelaskan kembali agar siswa dapat mengerti dan mengetahui kesalahan tersebut serta tidak terulang kembali. Jika ingin menggunkan sumber belajar untuk keterampilan siswa, hendaknya menggunakan sumber belajar yang ringan terlebih dahulu untuk perkenalan awal.

\section{DAFTAR PUSTAKA}

Akhadinah, S dkk. (2012). Pembinaan Kemampuan Menulis Bahasa Indonesia. Jakarta: Erlangga

Keraf, G. (2008). Diksi dan Gaya Bahasa. Jakarta: PT. Gramedia Pustaka Utama.

(2010). Argumentasi dan Narasi. Jakarta: PT. Gramedia Pustaka Utama.

Sugiyono. (2017). Metode Penelitian Kuntitatif, Kualitatif dan $R \& D$. Bandung: Alfabeta

Tarigan, H. G. (2008). Menulis sebagai Suatu Keterampilan Berbahasa. Jakarta: Angkasa. 